\title{
Placental Epigenome-Wide Association Study Identified Loci Associated with Childhood Adiposity at 3 Years of Age
}

\author{
Valérie Gagné-Ouellet ${ }^{1}$, Edith Breton ${ }^{1}$, Kathrine Thibeault ${ }^{1}$, Carol-Ann Fortin ${ }^{1}$, \\ Véronique Desgagné ${ }^{1,2}$, Élise Girard Tremblay ${ }^{1}$, Andres Cardenas ${ }^{3} \mathbb{B}$, Renée Guérin ${ }^{1,2}$, \\ Patrice Perron ${ }^{4,5}$, Marie-France Hivert ${ }^{4,6,7}$ and Luigi Bouchard ${ }^{1,2,5, *}$ \\ 1 Department of Biochemistry and Functional Genomics, Université de Sherbrooke, Sherbrooke, \\ QC J1H 5N4, Canada; valerie.gagne.ouellet@usherbrooke.ca (V.G.-O.); edith.breton@usherbrooke.ca (E.B.); \\ Kathrine.Thibeault@usherbrooke.ca (K.T.); Carol-Ann.Fortin@usherbrooke.ca (C.-A.F.); \\ Veronique.desgagne@usherbrooke.ca (V.D.); elise_g_t@hotmail.com (É.G.T.); \\ renee.guerin2@usherbrooke.ca (R.G.) \\ 2 Department of Medical Biology, CIUSSS Saguenay-Lac-Saint-Jean-Hôpital Universitaire de Chicoutimi, \\ Saguenay, QC G7H 5H6, Canada \\ 3 Division of Environmental Health Sciences, School of Public Health, University of California, \\ Berkeley, CA 94720-7360, USA; andres.cardenas@berkeley.edu \\ 4 Department of Medicine, Université de Sherbrooke, Sherbrooke, QC J1H 5N4, Canada; \\ Patrice.perron@usherbrooke.ca (P.P.); MHIVERT@PARTNERS.ORG (M.-F.H.) \\ 5 Centre de Recherche du CHUS, Sherbrooke, QC J1H 5N4, Canada \\ 6 Diabetes Unit, Massachusetts General Hospital, Boston, MA 02114, USA \\ 7 Department of Population Medicine, Harvard Pilgrim Health Care Institute, Harvard Medical School, \\ Boston, MA 02115, USA \\ * Correspondence: Luigi.bouchard@usherbrooke.ca
}

Received: 10 July 2020; Accepted: 21 September 2020; Published: 29 September 2020

check for updates

\begin{abstract}
The aim of this study was to identify placental DNA methylation (DNAm) variations associated with adiposity at 3 years of age. We quantified placental DNAm using the Infinium MethylationEPIC BeadChips. We assessed associations between DNAm at single-CpGs and skinfold thickness using robust linear regression models adjusted for gestational age, child's sex, age at follow-up and cellular heterogeneity. We sought replication of DNAm association with child adiposity in an independent cohort. We quantified placental mRNA levels for annotated gene using qRT-PCR and tested for correlation with DNAm. Lower DNAm at cg22593959 and cg22436429 was associated with higher adiposity $(\beta=-1.18, q=0.002$ and $\beta=-0.82, q=0.04)$. The cg22593959 is located in an intergenic region (chr7q31.3), whereas cg22436429 is within the TFAP2E gene (1p34.3). DNAm at $\operatorname{cg} 22593959$ and $\operatorname{cg} 22436429$ was correlated with mRNA levels at FAM3C $\left(\mathrm{r}_{\mathrm{s}}=-0.279, p=0.005\right)$ and TFAP2E $\left(\mathrm{r}_{\mathrm{s}}=0.216, p=0.03\right)$. In an independent cohort, the association between placental DNAm at $\operatorname{cg} 22593959$ and childhood adiposity was of similar strength and direction $(\beta=-3.8 \pm 4.1, p=0.36)$, yet non-significant. Four genomic regions were also associated with skinfold thickness within FMN1, MAGI2, SKAP2 and BMPR1B genes. We identified placental epigenetic variations associated with adiposity at 3 years of age suggesting that childhood fat accretion patterns might be established during fetal life.
\end{abstract}

Keywords: skinfolds thickness; epigenetics; fetal programming; DNA methylation; transcriptomics; EPIC array 


\section{Introduction}

Childhood obesity is now considered an overwhelming health problem as a consequence of a steadily rising prevalence over the last three decades [1]. In North America, as many as one-third of children are overweight or obese, and prevalence data are also concerning for developing countries $[2,3]$. Childhood obesity is associated with a wide range of complications (e.g., metabolic and cardiovascular dysfunctions) [4-6] with more than half of obese children at 5 years of age remaining obese in adulthood [7]. Therefore, unravelling its etiological factors and identifying early life biomarkers are essential steps to understand the pathophysiological processes leading to excess adiposity and improve childhood obesity prevention.

Recently, fat accretion and distribution patterns have emerged to be modulated by early-life determinants, suggesting that offspring's metabolic health might be, at least partially, dependent on the first 1000 days of life [8]. Epigenetic modifications are key players in transcriptional activity regulation and might well contribute to the programming of growth and development in the offspring as well as to fat accretion in childhood. Epigenetic modifications are responsive to pre- and perinatal metabolic and environmental stress, as this critical period is characterized by rapid cellular divisions and differentiations combined with a strong DNA methyltransferase (DNMT) activity [9-14]. DNMTs catalyze the addition of a methyl group on the fifth carbon of a pyrimidine ring of a cytosine base resulting in DNA methylation (DNAm), the most studied epigenetic modification.

To date, a few studies have investigated the association between DNAm profile and childhood obesity using different tissues and phenotypes [15]. Accordingly, several single-site DNAm variations (i.e., epimutations or epivariations) have been associated with children's body mass index (BMI), fat mass and skinfold thickness, but most of these were identified using a candidate gene approach and cross-sectional studies [16-28]. Although these studies may bring new insight into the research of childhood obesity's biomarkers and pathogenesis, longitudinal studies using unbiased genome wide approaches are of critical importance to identify novel genes and pathways leading to obesity. The few published epigenome-wide association studies (EWAS) reporting epimutations (e.g., KPRP, SCL9A10, MYLK2) associated with measures of adiposity in children from 4 months to 8 years old were all performed in cord blood [23,28-30]. Nevertheless, considering its fetal origin and its sensitivity to in utero environmental variations in order to orchestrate materno-fetal nutrient exchanges, the placenta has a unique potential to reveal the early-life origins of childhood obesity. Accordingly, it has been recently shown that the placental transcriptome is associated with childhood obesity. Although the underlying biological mechanisms are yet to be unraveled [31].

In this study, we have used skinfold thickness as a surrogate of body fatness as it shows the best correlations with DXA fat mass measures (the gold standard) in children and is much less affected by lean mass than the BMI or the BMI z-score [32]. Therefore, the main goal of this study was to identify placental CpG sites and epigenomic regions associated with skinfold thickness to better define the fetal epigenetic determinants of childhood obesity.

\section{Results}

\subsection{Participants Characteristics}

Table 1 presents clinical data for the 262 mother-offspring dyads from Gen3G. Mothers were on average $28.6 \pm 4.2$ years old, with a mean BMI of $25.5 \pm 5.5 \mathrm{~kg} / \mathrm{m}^{2}$, and presented with mean glucose $1 \mathrm{~h}$-post $50-\mathrm{g}$ glucose challenge test (GCT) of $5.0 \pm 2.2 \mathrm{mmol} / \mathrm{L}$ at the first trimester of pregnancy (9.8 \pm 2.3 weeks). At $24-28$ weeks, women completed a $75 \mathrm{~g}$ oral glucose tolerance test (OGTT) and the mean $2 \mathrm{~h}$ glucose concentration was $5.9 \pm 1.4 \mathrm{mmol} / \mathrm{L}$. At delivery, mean gestational age of the offspring was $39.6 \pm 1.0$ weeks with a mean birthweight of $3.4 \pm 0.4 \mathrm{~kg}$. At the 3 years old research visit, on average, offspring were aged $40.5 \pm 3.0$ months and had a BMI of $16.1 \pm 1.2 \mathrm{~kg} / \mathrm{m}^{2}$, with a mean BMI z-score slightly higher $(0.6 \pm 1.1 ; p<0.001)$ than their reference on the WHO growth chart (z-scores $=0)$. Mean $\Sigma$ ST was $17.5 \pm 3.6 \mathrm{~mm}$. 
Table 1. Characteristics of the mothers and children from Gen3G prospective cohort included in the analysis.

\begin{tabular}{|c|c|}
\hline Participants' Characteristics & Mean \pm SD \\
\hline \multicolumn{2}{|l|}{ Maternal characteristics } \\
\hline \multicolumn{2}{|l|}{ 1st trimester of pregnancy } \\
\hline Age (years) & $28.6 \pm 4.2$ \\
\hline $\mathrm{BMI}\left(\mathrm{kg} / \mathrm{m}^{2}\right)$ & $25.5 \pm 5.5$ \\
\hline \multicolumn{2}{|l|}{ Smoking during pregnancy } \\
\hline Yes & $7 \%$ \\
\hline No & $92 \%$ \\
\hline Unknown & $1 \%$ \\
\hline Glucose 1h-post 50g-GCT (mmol/L) & $5.0 \pm 2.2$ \\
\hline \multicolumn{2}{|l|}{ 2nd trimester of pregnancy } \\
\hline Fasting Glucose (mmol/L) & $4.2 \pm 0.3$ \\
\hline Glucose 2h-post 75g-OGTT (mmol/L) & $5.9 \pm 1.4$ \\
\hline Matsuda index & $8.7 \pm 5.3$ \\
\hline HDL-cholesterol (mg/dL) & $1.9 \pm 0.4$ \\
\hline LDL-cholesterol (mg/dL) & $3.5 \pm 0.9$ \\
\hline Triglycerides (mg/dL) & $1.8 \pm 0.5$ \\
\hline Total cholesterol (mg/dL) & $6.2 \pm 1.1$ \\
\hline \multicolumn{2}{|l|}{ 3rd trimester of pregnancy } \\
\hline $\begin{array}{l}\text { Gestational weight gain throughout } \\
\text { pregnancy }(\mathrm{kg})\end{array}$ & $11.4 \pm 9.5$ \\
\hline \multicolumn{2}{|l|}{ Child characteristics } \\
\hline \multicolumn{2}{|l|}{ At birth } \\
\hline Gestational age at birth (weeks) & $39.6 \pm 1.0$ \\
\hline \multicolumn{2}{|l|}{ Sex (Boys/Girls) } \\
\hline Boys & $55 \%$ \\
\hline Girls & $45 \%$ \\
\hline Birthweight (kg) & $3.4 \pm 0.4$ \\
\hline \multicolumn{2}{|l|}{ At 3 years old } \\
\hline Age (months) & $40.5 \pm 3.0$ \\
\hline Weight (kg) & $15.2 \pm 1.7$ \\
\hline $\operatorname{BMI}\left(\mathrm{kg} / \mathrm{m}^{2}\right)$ & $16.1 \pm 1.2$ \\
\hline Sum of skinfolds thicknesses (mm) & $17.5 \pm 3.6$ \\
\hline
\end{tabular}

The clinical characteristics of the 187 participants from the 3D cohort included in the replication analysis are shown in Table S1. Briefly, the mothers were on average slightly older ( $31.4 \pm 3.9$ years old; $p<0.001$ ) but leaner (BMI: $24.0 \pm 4.5 \mathrm{~kg} / \mathrm{m}^{2} ; p=0.003$ ) at first trimester of pregnancy when compared to Genetics of Glucose regulation in Gestation and Growth (Gen3G) mothers. Gestational age of the offspring at delivery ( $39.3 \pm 1.2$ weeks) was lower in comparison to Gen3G offspring $(p=0.02)$. Mean birthweight $(3.4 \pm 0.4 \mathrm{~kg} ; p=0.88)$ and early childhood $\Sigma \mathrm{ST}(16.9 \pm 4.9 \mathrm{~mm} ; p=0.25)$ were very similar to what we observed in Gen3G. However, 3D offspring were more than 1 year younger $(25.8 \pm 2.0$ months; $p<0.001)$ at the follow-up visit than the Gen3G offspring.

\subsection{Placental Epimutations Are Associated with Early-Childhood Adiposity in Gen3G Cohort}

Results of the epigenome-wide association analysis between placental DNAm and $\Sigma \mathrm{ST}$ are shown in Figure 1A. Across the epigenome, we detected one epimutation on chromosome 1 (cg22436429) and one on chromosome 7 (cg22593959) associated with $\Sigma$ ST at 3 years of age (False Discovery Rate, FDR, $\mathrm{q}<0.05)$ (Figure 1B). Lower placental DNAm levels at both cg22436429 $\left(\beta=-0.82 \pm 0.21, p=1.6 \times 10^{-7}\right.$, 
$q=0.04)$ and $\operatorname{cg} 22593959\left(\beta=-1.18 \pm 0.29, p=4.4 \times 10^{-9}, q=0.002\right)$ were associated with higher skinfold thickness at 3 years of age (Figure 2, Table 2).

A

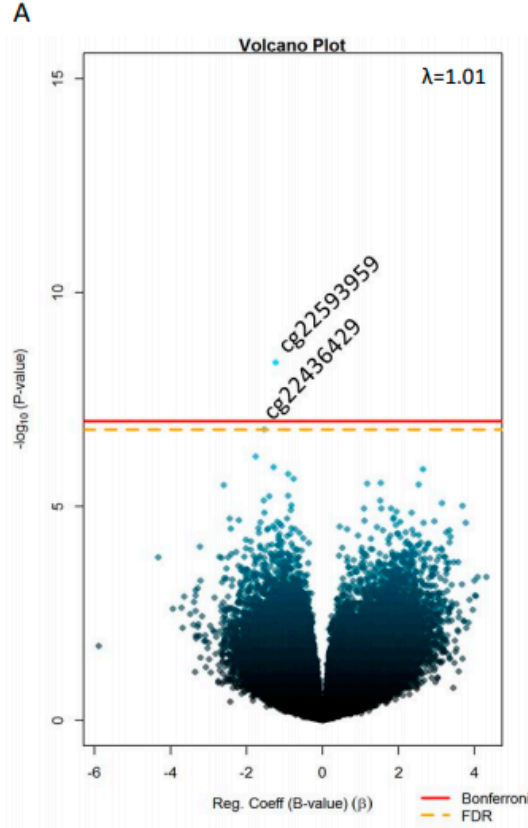

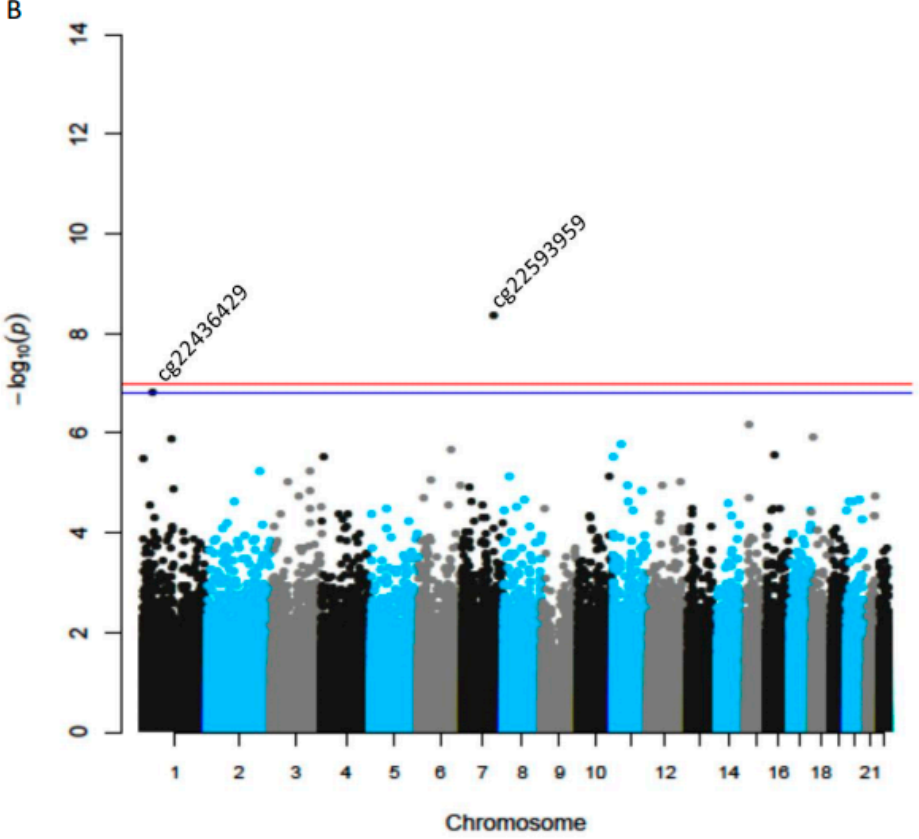

Figure 1. Epigenome-wide single-site associations between placental DNAm levels and childhood adiposity. (A) Volcano plot and (B) Manhattan plot shows the CpG-by-CpG analysis results of investigations between placental DNAm levels and children's sum of skinfolds (subscapular + tricipital) in Gen3G participants. The False Discovery Rate (FDR) correction for multiple testing threshold $(q<0.05)$ is represented by a yellow doted-line in the Volcano plot and a blue line in the Manhattan plot, whilst the red line is the Bonferroni-corrected threshold $\left(p<1 \times 10^{-7}\right)$ in both graphs.

A

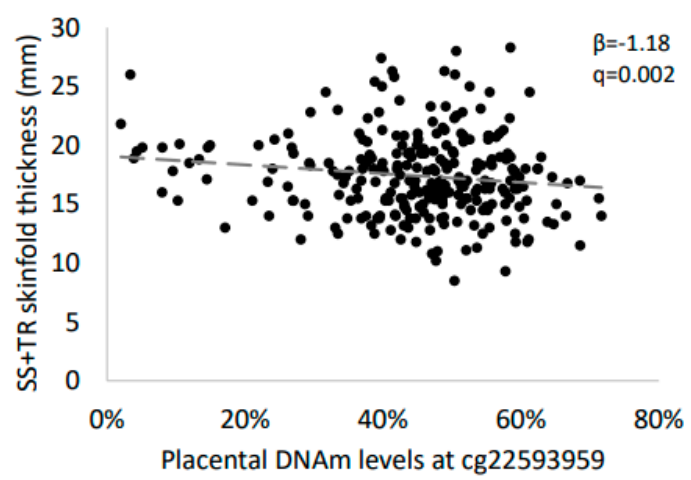

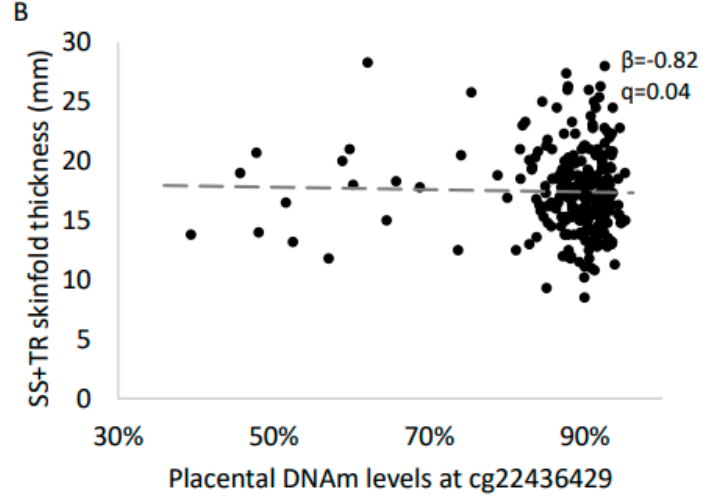

Figure 2. Association between DNAm levels at cg22593959 (A) and cg22436429 (B) and childhood adiposity. Robust linear regressions were computed in $\mathrm{R}$ with gestational age at birth, sex of the offspring, age at follow-up and cell composition estimation as covariates. Results were considered significant based on FDR correction for multiple testing $(q<0.05)$.

Table 2. Adjusted difference in skinfold thickness in early childhood with a $1 \%$ change in placental DNA methylation levels.

\begin{tabular}{ccccccccc}
\hline CpG & $\begin{array}{c}\text { Mean } \\
\text { DNAm (SD) }\end{array}$ & Gene & Chromosome & Position & $\begin{array}{c}\text { Gene } \\
\text { Group }\end{array}$ & $\begin{array}{c}\boldsymbol{\beta} \text { Coefficient } \\
\text { (SD) }\end{array}$ & $\boldsymbol{p}$ Value & $\boldsymbol{q}$ Value \\
\hline $\operatorname{cg} 22436429$ & $88(9) \%$ & TFAP2E & Chr 1 & $36,043,084$ & Body & $-0.82(0.21)$ & $1.6 \times 10^{-7}$ & 0.04 \\
$\operatorname{cg} 22593959$ & $45(13) \%$ & & Chr 7 & $121,184,995$ & & $-1.18(0.29)$ & $4.4 \times 10^{-9}$ & 0.002 \\
\hline
\end{tabular}


Interestingly, both $\mathrm{CPGs}$ are within DNase hypersensitivity regions located at Chr1:36,042,645-36,043,855 and Chr7:121,184,805-121,185,215 (based on ENCODE data). When comparing the genomic structure, cg22436429 is in a CpG island within the TFAP2E gene (1p34.3) whereas the cg22593959 is located in an intergenic region near the $7 \mathrm{q} 31.3$ locus, nearby CPDED1, WNT16 and FAM3C genes (Figures S1 and S2).

Regional analysis resulted in the identification of four additional loci associated with early-childhood adiposity (Table 3). The region with the strongest association (Sidak-adjusted $p=8.2 \times 10^{-6}$ ) contains six CpG sites (cg19635897, cg19599407, cg15175581, cg09347959, cg24543970 and cg25310250) and is located at the FMN1 gene locus on chromosome 15 (Figure S3). Differentially methylated regions (DMRs) within the MAGI2 $\left(p=8.8 \times 10^{-6}\right)$ and SKAP2 $\left(p=9.3 \times 10^{-5}\right)$ genes, which are both located on chromosome 7 (Figures S4 and S5), harbor seven (cg07448060, cg17463145, cg21784917, cg20996682, cg13382769, cg07985720 and cg24391460) and three CpG sites (cg20747577, cg11497410 and cg07473340), respectively. The last region $\left(p=2.6 \times 10^{-5}\right)$ within the BMPR1B (chromosome 4) had the highest number of CpG sites with nine (cg21066876, cg26878941, cg25288803, cg22273744, cg10549916, cg09771641, cg26603183, cg07341914 and cg22572902) (Figure S6). Lower DNAm levels at all four identified regions were associated with higher sums of skinfolds (Table S2).

Table 3. Regional placental DNA methylation associated to early-childhood adiposity.

\begin{tabular}{|c|c|c|c|c|c|c|c|}
\hline Chromosome & $\begin{array}{c}\text { Start } \\
\text { Position }\end{array}$ & $\begin{array}{c}\text { End } \\
\text { Position }\end{array}$ & $\underset{\text { Value }}{\text { Minimal } p}$ & $\begin{array}{l}\text { Nbr of } \\
\text { CpGs }\end{array}$ & $\begin{array}{c}\text { Sidak-Adjusted } \\
p \text { Value }\end{array}$ & Gene & $\begin{array}{c}\text { Direction of the } \\
\text { Association }\end{array}$ \\
\hline 4 & $95,972,466$ & $95,972,790$ & $4.0 \times 10^{-4}$ & 9 & $2.6 \times 10^{-5}$ & $B M P R 1 B$ & - \\
\hline 7 & $26,897,253$ & $26,897,522$ & $2.0 \times 10^{-4}$ & 3 & $9.3 \times 10^{-5}$ & $S K A P 2$ & - \\
\hline 7 & $79,083,753$ & $79,084,166$ & $1.2 \times 10^{-5}$ & 7 & $8.8 \times 10^{-6}$ & MAGI2 & - \\
\hline 15 & $33,360,195$ & $33,360,337$ & $2.0 \times 10^{-4}$ & 6 & $8.2 \times 10^{-6}$ & FMN1 & - \\
\hline
\end{tabular}

\subsection{Sex-Specific Effect of Fetal Programming of Adiposity}

We further explored whether the identified epimutations and regions associated with early-childhood adiposity were influenced by sex. We did not observe significant interactions between sex and DNAm levels, yet at some identified regions, the associations seemed to be preferentially driven by one of the child sex strata (based on regression coefficients). Except for the region located on chromosome 4 (BMPR1B; position 95,972,466-95,972,790) where regression $\beta$ coefficients were stronger in girls, the association with the three other regions (FMN1; chr 15: 33,360,195-33,360,337, MAGI2; chr 7: 79,083,753-79,084,166 and SKAP2; chr 7: 26,897,253-26,897,522) seemed to be driven by boys, although significant associations were observed with both sexes for most DMRs (Table S3).

\subsection{Epigenetic Regulation of Gene Expression}

Placental mRNA levels of genes located nearby the two epimutations identified (WNT16, FAM3C, CPED1 and TFAP2E) and within the four regions (FMN1, MAGI2, SKAP2 and BMPR1B) were quantified and tested for association with placental DNAm levels (Table 4) and offspring $\Sigma S T$ at 3 years of age. We first investigated the association between DNAm levels at cg22593959 and FAM3C and CPED1 mRNA levels: WNT16 mRNA was barely detectable and too weak to be further analyzed. We found that FAM3C DNAm was negatively correlated with its mRNA levels $\left(\mathrm{r}_{\mathrm{s}}=-0.279, p=0.005\right)$ (Figure 3A) whereas DNAm levels at cg22436429 were associated with lower TFAP2E gene levels $\left(r_{s}=0.216\right.$, $p=0.03$ ) (Figure 3B). As outliers were previously removed with gaphunter, all data were kept in the analysis. We did not observe significant association between mRNA levels of FAM3C or TFAP2E and skinfold thickness (data not shown). None of the four regions identified by comb-p were associated with mRNA levels at their respective gene locus (Table 4). 
Table 4. Association between DNAm levels at both single-site and epigenomic regions, and transcriptional activity.

\begin{tabular}{ccc}
\hline cg or Epigenomic Region & Gene & Correlation \\
\hline \multirow{2}{*}{$\operatorname{cg} 22593959$} & CPED1 & $\begin{array}{c}\mathrm{r}_{\mathrm{s}}=-0.111 \\
p=0.28\end{array}$ \\
\cline { 2 - 3 } & WNT16 & Not detected \\
\cline { 2 - 3 } $\operatorname{cg} 22436429$ & FAM3C & $\begin{array}{c}\mathrm{r}_{\mathrm{S}}=-0.279 \\
p=0.005\end{array}$ \\
\hline \multirow{2}{*}{ TMN1 } & TFAP2E & $\begin{array}{c}\mathrm{r}_{\mathrm{S}}=0.216 \\
p=0.03\end{array}$ \\
\hline \multirow{2}{*}{ FAGI2 } & FMN1 & $\mathrm{r}_{\mathrm{s}}=-0.004$ \\
$p=0.97$
\end{tabular}
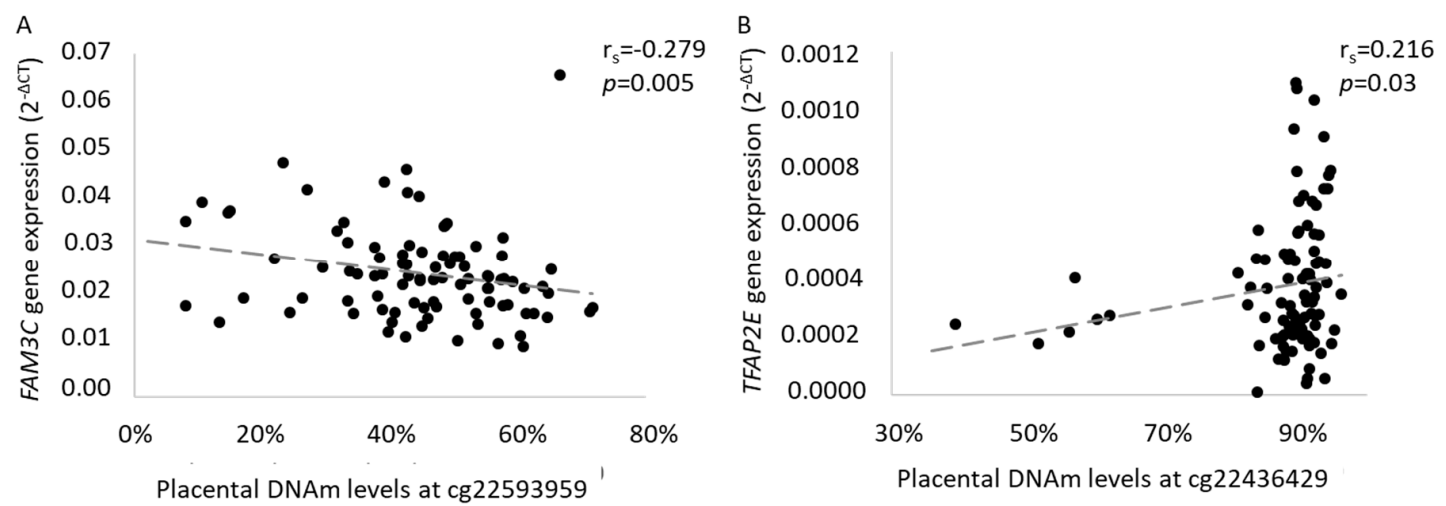

Figure 3. Associations between placental DNAm levels between (A) cg22593959 and FAM3C mRNA levels and (B) cg22436429 and TFAP2E mRNA levels. Spearman's correlation tests were computed for each significant epimutations in the Gen3G cohort and mRNA levels of nearby or covering genes quantified relatively to the endogenous control YWHAZ.

\subsection{Association between Maternal Characteristics and Placental Epimutations}

We then tested the association between maternal anthropometric and metabolic profile and DNAm levels at both epimutations associated with $\Sigma$ ST. As shown in Table S4, placental DNAm levels at cg22593959 were not associated to maternal characteristics during pregnancy whereas cg22436429 was associated, although modestly, to the maternal blood lipid profile at the second trimester of pregnancy (low-density lipoprotein-cholesterol (LDL-C): $\beta=0.142, p=0.03$; total cholesterol: $\beta=-0.128, p=0.05$ ).

\subsection{Replication of CpG-by-CpG EWAS Results in 3D Birth Cohort}

We sought to replicate our CpG-by-CpG significant sites (cg22593959 and cg22436429) in an independent birth cohort. Interestingly, the strength (based on $\beta$ coefficients) and direction of the association between DNAm levels at cg22593959 and $\Sigma$ ST was similar in Gen3G ( $\beta=-3.8 \pm 4.1$ vs. $-1.18 \pm 0.29$; Figure $4 \mathrm{~A}$ ), but not for $\operatorname{cg} 22436429$ ( $\beta=0.07 \pm 3.00$ vs. $-0.82 \pm 0.21$; Figure $4 \mathrm{~B}$ ). We also performed fine-mapping around the significant $\mathrm{CpG}$ sites. However, none of the other $\mathrm{CpG}$ sites tested nearby the $\operatorname{cg} 22593959$ nor within the TFAP2E gene locus were associated with childhood adiposity in 3D cohort (Table S5). 


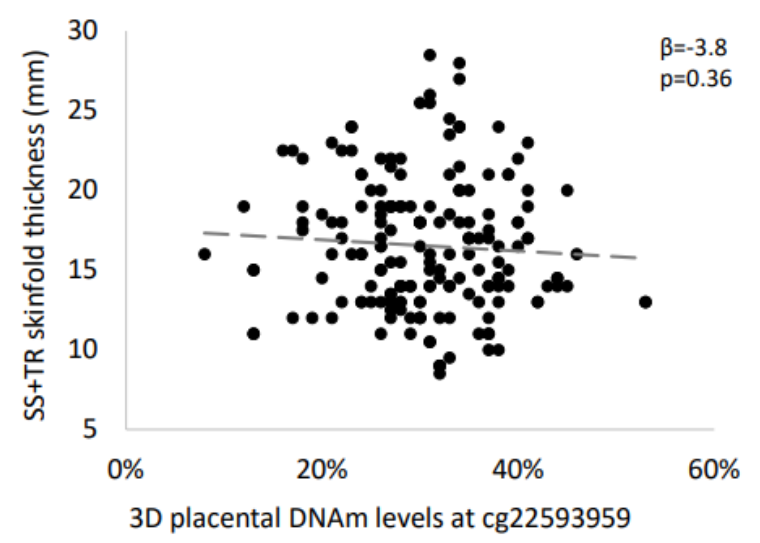

(A)

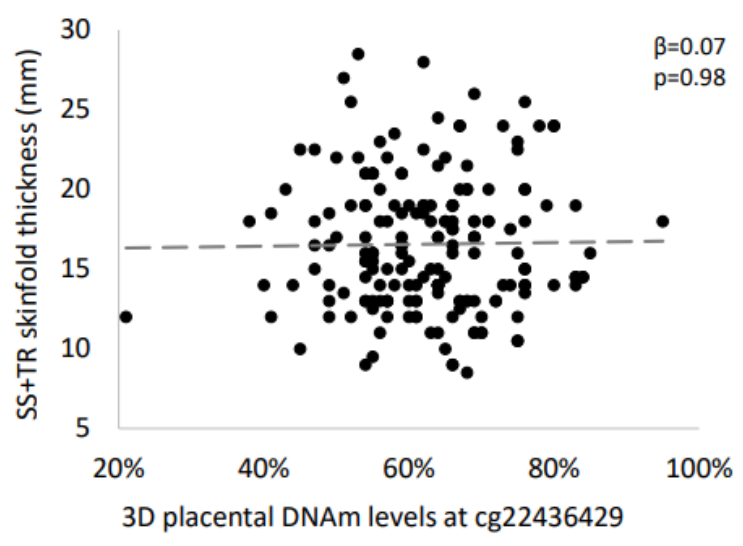

(B)

Figure 4. Association between placental DNAm levels at significant CpG sites and early-childhood adiposity in the independent 3D birth cohort. Spearman's correlation tests were used to assess the association between skinfold thickness and DNAm levels at (A) cg22593959 and (B) cg22436429.

\section{Discussion}

In the current study, we identified two CpG sites and four regions at which placental DNAm levels were associated with children's skinfold thickness [32,33]. Among the two CpGs, one was located within an intergenic region (locus 7q31.3) nearby the WNT16-FAM3C-CPED1 locus, previously associated with metabolic syndrome [34], whereas the other was located within the TFAP2E gene locus. The two identified epimutations (i.e., cg22593959 and cg22436429) are likely regulating transcriptional activity of the FAM $3 C$ and TFAP2E genes, respectively, as supported by our expression analyses. Additionally, we identified four candidate epigenomic regions associated with skinfold thickness, which were located within FMN1, MAGI2, SKAP2 and BMPR1B genes. Altogether, these results bring new supporting evidence that placental DNAm variation might predict fat accretion in early childhood.

Within the 7q31.3 locus, FAM3C seems the best potential target functionally related to the intergenic epimutation cg22593959. This is the only gene among the three tested showing correlation between the DNAm and mRNA levels. FAM3C is an ubiquitously expressed gene classified among the family with sequence similarity 3 (FAM3) gene family, which is involved in the regulation of hepatic glucose and lipid metabolism [35]. Although its specific role in energy regulation is still unclear, FAM3C overexpression in the liver of diabetic obese mice has been associated with improved glucose tolerance and insulin sensitivity [36]. Biologically, FAM3C upregulates Akt phosphorylation, which reduces neoglucogenesis and lipogenesis (and indirectly promotes lipolysis) [36]. FAM3C is also suspected to be involved in osteogenic cell differentiation [37] suggesting it might also have a role in adipogenesis. Indeed, osteogenesis and adipogenesis are closely related processes, especially since bone marrow-derived stromal cells (BMSCs) are multipotent cells that differentiate into lineages of mesenchymal tissues, such as chondrocytes, osteoblasts and adipocytes [38,39]. Together, these findings suggest that $F A M 3 C$ epigenetic dysregulation could have shorter- and also longer-term impacts on the development of obesity. However, although placental FAM3C gene expression was not associated with early-childhood skinfold thickness in our study, it is possible that higher placental levels of FAM3C gene expression (associated to lower DNAm levels) may reflect FAM3C mRNA levels in other metabolically active tissues (e.g., adipose tissue) and therefore lead to greater adiposity. This will have to be assessed in further studies.

On the other hand, TFAP2E encodes a protein (AP-2E) in the transcriptional regulation by the AP-2 (TFAP2) family. This family includes transcription factors that bind to a DNA consensus sequence to activate several genes with biological functions in embryogenesis and growth of organs including eyes, face, skin and particularly central nervous system (CNS) [40,41]. The role of the central nervous system in food intake and energy homeostasis regulation is now well established [42]. In addition, 
as it was shown in mice and humans, this protein is highly suspected to orchestrate chondrogenesis and differentiation of muscle cells in embryos [43-46]. We herein reported that lower DNAm levels at cg22436429 were associated to lower TFAP2E gene expression in placenta and higher early-childhood adiposity. It is plausible that this gene might have protective effects against obesity. Hence, an epigenetic perturbation might lead to decreased rates of TFAP2E in embryos and might alter CNS or BMSCs normal development with further consequences on fat accretion. Interestingly, another member of the AP-2 family (TFAP2B) has been widely studied for its association with obesity and BMI variability [47-51], reinforcing that the AP-2 family has a crucial role to play in the development of obesity.

We also identified candidate placental epigenomic regions associated with early-childhood adiposity (i.e., FMN1, MAGI2, SKAP2, and BMPR1B), but we could not identify their functionally related target gene in the placenta, as DNAm levels within these regions were not associated with mRNA levels of the nearby genes. However, in light of our results, it is not possible to rule out that DNAm at these loci might be associated with their respective gene expression in other tissues and/or developmental windows. Still, whether through the regulation of BMSCs differentiation (FMN1 and $B M P R 1 B)$, glucose metabolism (MAGI2), or initiation of the inflammatory process (SKAP2), these genes could be relevant to the development of obesity [52-55].

\section{Strength and Limitations}

Only a few studies assessed the longitudinal implication of the fetal methylome in the development of childhood excess fat accretion [56]. The use of a large number of full-term placentas from a longitudinal cohort is a strength of the study. Gen3G is a well-phenotyped prospective cohort: we recruited women at first trimester of pregnancy, and we followed mother-child pairs prospectively during childhood. We measured DNAm levels using the latest Illumina MethylationEPIC microarray, covering $>850,000 \mathrm{CpG}$ sites across the human genome. Few currently published studies used the MethylationEPIC microarray and only one was performed to assess the association between leucocytes DNAm levels and obesity traits [56]. In addition, the similar direction of effect of the association between placental DNAm levels at cg22593959 and childhood total adiposity in an independent cohort supports the findings reported in the Gen3G cohort. However, the result of our replication did not reach statistical significance, which could be explained by the lower age at follow-up in 3D birth cohort, our incapacity to adjust the replication results for placental cell type heterogeneity, and/or differences in the sample collection procedure. Finally, the sample size might also have limited our ability to detect more modest effects of placental DNAm on childhood adiposity. EWAS (such as Genome-wide association studies, GWAS) results replication is challenging, needs time and performance in multiple cohorts before clear conclusion can be drawn. Accordingly, and even after considering the limitations reported above, our replication analyses should be considered as a strength especially as it supports in strengths and direction the association with cg22593959. Some other limitations are noteworthy to mention. Accordingly, although our study was conducted in Gen3G, a thoroughly phenotyped prospective birth cohort, we did not identify maternal factors potentially programming the epimutations reported in this study. Interestingly, maternal lipid profile (i.e., plasma LDL-C and total cholesterol concentrations) at the second trimester of pregnancy was modestly associated with DNAm levels at cg22436429 (within TFAP2E), but not with childhood adiposity. Moreover, the placental epimutations were not found to be correlated with maternal hyperglycemia as in a previous study from our group [57], suggesting that other maternal pregnancy factors may be responsible for programming these placental epigenetic disturbances $[58,59]$. Identified epivariations are likely to be either influenced by genetic factors or the consequences of fetal programming as they are untainted by post-natal exposures. 


\section{Materials and Methods}

\subsection{Genetics of Glucose regulation in Gestation and Growth (Gen3G) cohort Characteristics}

Study participants were selected among the Genetics of Glucose regulation in Gestation and Growth (Gen3G) prospective birth cohort described previously [60]. Briefly, mothers were recruited during their first trimester of pregnancy. They fulfilled inclusion criteria if they were $\geq 18$ years old, without pre-pregnancy diabetes and with a singleton pregnancy. Mother-child dyads were excluded if they encountered severe complication during pregnancy (e.g., high blood pressure or pre-eclampsia). A total of 262 participants were included in this study based on the availability of placental samples and if they had completed a $2 \mathrm{~h}$ post-75 g oral glucose tolerance test (OGTT; diagnosis test for gestational diabetes mellitus (GDM)) data between the 24th-28th weeks of pregnancy, gestational age $\geq 37$ weeks of gestation at delivery and offspring's indicators of adiposity at 3 years old. All mothers provided written consent at recruitment. This project was conducted in accordance with the Declaration of Helsinki and approved by the Centre Hospitalier Universitaire de Sherbrooke (CHUS) ethics committee (Project \#2010-198, 07-027-A1, initially approved on September 2010 and renewed on 11th September 2020).

\subsection{Replication: 3D Cohort Study (Design, Develop, Discover) Characteristics}

For the replication study, 187 participants were randomly selected among the 3D Cohort Study (Design, Develop, Discover), a prospective pregnancy and birth cohort previously described [61,62]. Briefly, nine sites in Quebec recruited pregnant women and their partner during the first trimester of pregnancy and followed postnatally through 2 years after delivery. The replication study included 187 participants with available placenta samples, based on the following inclusion criteria: Caucasian with gestational age $\geq 37$ weeks of gestation at delivery and adiposity measures in their child at 2 years of age. Participants with pre-gestational diabetes (Type 1 or 2) were excluded, alongside those with gestational hypertension or pre-eclampsia. All mothers gave written informed consent before enrollment in the study, in accordance with the Declaration of Helsinki.

\subsection{Offspring's Adiposity Measure in Gen3G and 3D Cohorts}

In both cohorts, BMI was assessed and computed as z-scores based on the World Health Organization (WHO) growth chart reference for boys and girls. Subscapular (SS) and tricep (TR) thickness to the nearest $0.1 \mathrm{~mm}$ were measured by a Holtain skinfold caliper (Holtain Ltd., Crosswell, UK). The sum of SS and TR skinfolds ( $\Sigma S T=S S+T R)$ was used as a proxy for overall adiposity $[57,62]$ as it was previously associated with DNAm marks in cord blood [28]. Children from Gen3G with extreme values of BMI $\left(\mathrm{n}=1 ; 33.6 \mathrm{~kg} / \mathrm{m}^{2}\right)$ or $\Sigma S T(\mathrm{n}=2 ; 8.5$ and $48.5 \mathrm{~mm})$ were excluded as they were $>3$ interquartile ranges (IQR) from the median.

\subsection{Sample Collection and Nucleic Acids Extraction in Both Cohorts}

Placental samples were collected after delivery $(<30 \mathrm{~min})$ by well-trained research staff. A total of $1 \mathrm{~cm}^{3}$ was collected on the fetal side, near the umbilical cord insertion $(\leq 5 \mathrm{~cm})$ and Gen $3 \mathrm{G}$ samples were kept in RNAlater (Qiagen, Germantown, MD, USA). Samples from both cohorts were kept at $-80{ }^{\circ} \mathrm{C}$ until DNA extraction. DNA and RNA were extracted using the All Prep DNA/RNA/Protein Mini Kit (Qiagen, Germantown, MD, USA) for both cohorts. Double strand DNA concentration were assessed using Quant-iT ${ }^{\mathrm{TM}}$ PicoGreen $^{\mathrm{TM}}$ dsDNA Assay Kit (Qiagen, Germantown, MD, USA). Sodium-bisulfite conversions were performed prior to epigenome-wide methylation analyses following recommendations of the EpiTect Bisulfite Kit (Qiagen, Germantown, MD, USA). RNA concentrations and RNA integrity number (RIN) (mean $8.3 \pm 0.9$ ) were assessed with Agilent 2100 Bioanalyzer (Agilent RNA 6000 Nano Kit, Agilent Technologies, Santa Clara, CA, USA). Samples with RIN < 6 were excluded. 


\subsection{Infinium MethylationEPIC BeadChips in Gen3G Samples}

In a previous study from our group [57], epigenome-wide DNAm levels were quantified in 448 placenta samples from the Gen3G placenta samples cohort using the Infinium MethylationEPIC BeadChip (Illumina, USA), which provides an improved coverage (i.e., $850 \mathrm{k} \mathrm{CpG}$ sites across the human genome) of enhancer and regulatory regions compared to the previous technologies [63,64].

Briefly, the samples were localized in random positions in both plates and chips to limit the impact of technical bias [57]. The preprocessing step performed on the overall samples included intra-sample quality controls (QCs) and probes clean-up steps using minfi library in R (Figure S7) [65]. Briefly, the QCs excluded samples that failed $(n=5)$ and with genotype $(n=6)$ and sex $(n=1)$ mismatches, alongside with technical duplicated $(n=10)$. From the original 448 placenta DNA samples from our previous study [57], 262 had offspring's adiposity measures at 3 years old and were hence retained for the present study. First, data were processed using functional normalization with two principal components from control probes as a default [66]. The probe-type bias was then adjusted with Regressions on Correlated Probes (RCP), a method based on genomic vicinity to adjust type 2 probe distributions [67]. Detection $p$-values were computed and probes that did not reach significance for detection $(p>0.05)$ in $5 \%$ or more of the samples were excluded ( $n=145$ probes). Sex-chromosome-associated probes $(n=19,536)$, non-CpG probes $(n=2839)$ and SNP-associated probes (i.e., directly under the probe or at the single base extension at the CpG site $(n=83,222)$ and at CpG sites $(n=6075)$ with a minor allele frequency $\geq 5 \%$ were excluded from the analyses. The annotated probes suspected to be affected by cross-hybridization were also removed $(n=34,088)$ [63]. In addition, only probes with mean DNAm levels between 5 and $95 \%$ were retained for further analytical steps in the current analyses $(n=494,048)$ to avoid probes that show extreme levels of low or high DNAm [68]. Adjustment for potential technical bias was performed using the ComBat function from the sva package in R [69]. CpGs with DNAm level gaps $>30 \%$ were identified (outliers) and removed using the gaphunter function ( $n=5198$ data points distributed among the $494 \mathrm{k}$ probes) [70]. Prior to the analyses, the raw DNAm values were logit transformed into M-values to better fulfill regression modeling assumptions, although the effects were reported with the raw DNAm values to ease interpretation [71].

\subsection{Gene Expression Analysis}

To assess potential functionality in placenta of our top signals, RNA from a subset of 105 participants from the Gen3G cohort with both DNAm data and skinfold thickness measures at 3 years old was selected (RIN $8.3 \pm 0.9$ ). Prior to the amplification, complementary DNA (cDNA) has been generated with the High Capacity cDNA RT Kit (Thermofisher, Waltham, MA, USA). The quantitative real-time PCR (qRT-PCR) analyses were performed in duplicate using TaqMan ${ }^{\circledR}$ Fast Universal PCR Master Mix (Thermofisher, Waltham, MA, USA). The mRNA levels were quantified for the genes located in the locus 7q31.3 (FAM3C: Hs02836787_g1, WNT16: Hs00365138_m1, CPED1: Hs00227735_m1), TFAP2E (Hs00698734_m1), FMN1 (Hs01396838_m1), MAGI2 (Hs00202321_m1), SKAP2 (Hs00919389_g1) and BMPR1B (Hs01010965_m1) (Thermofisher, Waltham, MA, USA) using the TaqMan ${ }^{\circledR}$ Gene Expression Assays (Thermofisher, Waltham, MA, USA). The analyses were performed using the 7500 Real-Time PCR system (Thermofisher, Waltham, MA, USA). The qRT-PCRs were performed using 7500 Real-Time PCR system (Thermofisher, Waltham, MA, USA). The YWHAZ (Hs01122445_g1, Thermofisher, Waltham, MA, USA) was used as a reference gene as it was reported as stable in human placenta [72-74].

\subsection{EpiTYPER Massarray in 3D Samples}

The EpiTYPER Massarray (Sequenom ${ }^{\circledR}$, San Diego, CA, USA) approach was used to quantify DNAm levels in the placenta samples from the 3D Cohort at Genome Quebec. Briefly, this approach is based on the analysis of amplified bisulfite treated DNA followed by in vitro RNA transcription, uracile-specific cleavage and fragments analysis using MALDI-TOF mass spectrometry. The RNA fragments differ in size and mass depending of the methylation of the cytosines within the targeted 
sequence and the DNAm levels are determined using the EpiTYPER software. The PCR primers for the cg22436429 (and 30 more CpG in the vicinity) were: 5'-AGGTAGGTGGGTTTTTTGTTTTTT-3' and 5'-ACTTTTCCAACCCAAATCTAAACC-3', whereas the primers for the cg22593959 (and another CpG site nearby) were: 5'-AAGTGTGTGTTTGGTTTTGTTATAGG-3' and $5^{\prime}$-AAAAACATCATATCATTAAAAATCCTC-3'. Five of the 187 DNA samples sent for replication analysis failed to amplify.

\subsection{Statistical Analysis}

The CpG-by-CpG analyses were all performed with $\mathrm{R}$ using individual robust linear regression models with placental DNAm on the M-value scale as the predictor and early-childhood adiposity represented by $\Sigma \mathrm{ST}$ as the outcome in the Gen3G cohort. Robust linear regression was used to address potential heteroskedasticity [75]. Gestational age at delivery, sex of the offspring and its age at follow-up were included in the regression models as covariates. Analyses were also adjusted for cell composition heterogeneity using the first 5 principal components from ReFACTor, a reference-free method adjusting for cell-type heterogeneity adapted for all tissue, including placenta [76]. Inflation $(\lambda)$ was assessed using quantile-quantile plots of $p$-values after adjustment for cellular heterogeneity (Figure S8). After adjustments, $\lambda$ was 1.01. The reported results were all FDR-significant ( $q$-value $<0.05)$. We also identified Bonferroni-significant probes $\left(p<1 \times 10^{-7} ; 0.05 / 494048\right.$ probes).

We further assessed epigenomic regions associated with early-childhood adiposity. To perform regional analysis, we used comb-p, a Python library, to determinate $\Sigma$ ST-associated differentially methylated regions (DMRs) in placenta [77]. Briefly, comb-p adjusts $p$-values from CpG-by-CpG regression models using the Stouffer-Liptak correction for highly autocorrelated CpGs within a 1000bp window and therefore combines the p-values. Combined $\mathrm{p}$-values were adjusted for multiple testing with Sidak, which considers the number of potential regions created. DMRs were considered significant when $p<0.05$. Regional association plots were computed with the R package comet.

The associations between DNAm levels and gene expression were investigated only for the placenta genes annotated or within $200 \mathrm{~kb}$ of the two FDR significant CpG sites. Normality was assessed using a Shapiro-Wilk distribution test and as both DNAm and mRNA levels were not distributed normally, even after log adjustment, we performed non-parametric tests. Spearman's correlation tests were used to assess the statistical association between DNAm and mRNA levels. We also investigated the potential contribution of maternal anthropometric (e.g., pre-pregnancy BMI) and metabolic profile during pregnancy as we assessed the association between DNAm levels at significant epimutations and maternal variables using Spearman's correlation tests.

As only epimutations from $\mathrm{CpG}-\mathrm{by}-\mathrm{CpG}$ were significantly associated with their respective gene expression, we only investigated these regions in the replication analysis. Linear regression models were used to investigate the association between significant placental epimutations and nearby CpG sites, and $\Sigma$ ST at 2 years old in DNA samples from 3D cohort. Replication and fine-mapping results were considered significant when $p<0.05$. Spearman's correlation and linear regression tests were performed on SPSS software (v25.0.0, IBM, USA, https://www.ibm.com/analytics/spss-statistics-software).

\section{Conclusions}

Our results suggest that placental DNAm levels measured at birth at specific loci are associated to early-childhood adiposity. The reported results support that the DNAm markers we identified in our CPG-by-CpG analyses might possibly induce a dysregulation of FAM3C and TFAP2E expression in placental tissues. These findings could provide new insights into the development of childhood obesity and provide potential new biomarkers for screening children at-risk of obesity as soon as at birth. 
Supplementary Materials: Supplementary Materials can be found at http://www.mdpi.com/1422-0067/21/19/ 7201/s1. Figure S1: Schematic representation of the preprocessing steps including probes quality controls and clean-up, Figure S2: QQ-plot for the association between placental methylome and childhood adiposity, Figure S3: Regional association plot and correlation heatmap of CpGs located near cg22593959 from the CpG-by-CpG analysis, Figure S4: Regional plot and correlation heatmap of CpGs located near cg22436429 from the CpG-by-CpG analysis, Figure S5: Regional plot and correlation heatmap of CpGs located in the FMN1 gene locus from the regional analysis, Figure S6: Regional plot and correlation heatmap of CpGs located in the MAGI2 gene locus from the regional analysis, Figure S7: Regional plot and correlation heatmap of CpGs located in the SKAP2 gene locus from the regional analysis, Figure S8: Regional plot and correlation heatmap of CpGs located in the BMPR1B gene locus from the regional analysis, Table S1: Characteristics of the mothers and children from 3D prospective cohort and comparison with Gen3G, Table S2: Detailed EWAS results for the epigenomic regions associated with early-childhood adiposity in the Gen3G cohort, Table S3: Sex-stratification of associations between placental DNAm levels at epimutation sites and early-childhood adiposity in the Gen3G cohort, Table S4: Associations between placental DNA methylation levels in significant CpG sites and anthropometric and metabolic profile of mothers from the Gen3G birth cohort, Table S5: Associations between placental DNA methylation levels in fine-mapped CpG sites and sum of skinfold thickness in children at 2 years of age from the 3D birth cohort.

Author Contributions: Conceptualization, R.G., P.P., M.-F.H. and L.B.; formal analysis, V.G.-O.; funding acquisition, P.P., M.-F.H. and L.B.; investigation, V.G.-O.; methodology, V.G.-O., E.B., K.T., C.-A.F., V.D., É.G.T. and A.C.; project administration, V.G.-O. and L.B.; resources, M.-F.H. and L.B.; software, V.G.-O. and M.-F.H.; supervision, M.-F.H. and L.B.; validation, M.-F.H. and L.B.; writing-original draft, V.G.-O.; writing-review and editing, E.B., K.T., C.-A.F., V.D., É.G.T., A.C., R.G., P.P., M.-F.H. and L.B. All authors have read and agreed to the published version of the manuscript.

Funding: L.B. is a senior research scholar from the Fond de la recherche du Québec en santé (FRQS). L.B., M.-F.H. and P.P. are members of the FRQS-funded Centre de recherche du CHUS (affiliated to the Centre hospitalier universitaire de Sherbrooke). V.G.-O. received a doctoral research award from the FRQS in partnership with the Foundation of Stars while E.B. and K.T. had a master's degree research award from the FRQS.

Acknowledgments: The authors want to thank the participants from both Gen3G and 3D cohort and Genome Quebec.

Conflicts of Interest: The authors declare no conflict of interest. The funders had no role in the design of the study; in the collection, analyses, or interpretation of data; in the writing of the manuscript, or in the decision to publish the results.

Ethical Standards: The Chicoutimi Hospital Ethics Committee approved the project, along with the ethical review board from the Centre hospitalier universitaire de Sherbrooke. All women provided a written informed consent before their inclusion in the study, in accordance with the Declaration of Helsinki.

$\begin{array}{ll}\text { Abbreviations } & \\ \text { BMI-z } & \text { body mass index z-scores } \\ \text { BMPR1B } & \text { bone morphogenetic protein receptor type 1B } \\ \text { BMSC } & \text { bone marrow-derived stromal cells } \\ \text { CPED1 } & \text { cadherin-like and PC-esterase domain containing 1 } \\ \text { CNS } & \text { central nervous system } \\ \text { DMR } & \text { differentially methylated region } \\ \text { DNAm } & \text { DNA methylation } \\ \text { DNMT } & \text { DNA methyltransferase } \\ \text { EWAS } & \text { epigenome-wide association study } \\ \text { FAM3C } & \text { family with sequence similarity 3 member C } \\ \text { FMN1 } & \text { formin 1 } \\ \text { GCT } & \text { glucose challenge test } \\ \text { GDM } & \text { gestational diabetes mellitus } \\ \text { Gen3G } & \text { Genetics of Glucose regulation in Gestation and Growth } \\ \text { HDL-C } & \text { high-density lipoprotein cholesterol } \\ \text { IQR } & \text { interquartile range } \\ \text { LDL-C } & \text { low-density lipoprotein cholesterol } \\ \text { MAGI2 } & \text { membrane-associated guanylate kinase } \\ \text { QC } & \text { quality control } \\ \text { RIN } & \text { RNA integrity number } \\ & \end{array}$




$\begin{array}{ll}\text { SKAP2 } & \text { Src kinase-associated phosphoprotein } 2 \\ \text { SS } & \text { suprascapular } \\ \text { ST } & \text { skinfold thickness } \\ \text { TFAP2E } & \text { transcription factor AP-2 epsilon } \\ \text { TR } & \text { tricipital } \\ \text { WHO } & \text { World Health Organization } \\ \text { WNT16 } & \text { Wnt family member } 16\end{array}$

\section{References}

1. Swinburn, B.A.; Sacks, G.; Hall, K.D.; McPherson, K.; Finegood, D.T.; Moodie, M.L.M.; Gortmaker, S.L. The global obesity pandemic: Shaped by global drivers and local environments. Lancet 2011, 378, 804-814. [CrossRef]

2. Rao, D.P.; Kropac, E.; Do, M.T.; Roberts, K.C.; Jayaraman, G.C. Childhood overweight and obesity trends in Canada. Health Promot. Chronic Dis. Prev. Can. 2016, 36, 194-198. [CrossRef] [PubMed]

3. Ng, M.; Fleming, T.; Robinson, M.; Thomson, B.; Graetz, N.; Margono, C.; Mullany, E.C.; Biryukov, S.; Abbafati, C.; Abera, S.F.; et al. Global, regional, and national prevalence of overweight and obesity in children and adults during 1980-2013: A systematic analysis for the Global Burden of Disease Study 2013. Lancet 2014, 384, 766-781. [PubMed]

4. Guo, S.S.; Chumlea, W.C. Tracking of body mass index in children in relation to overweight in adulthood. Am. J. Clin. Nutr. 1999, 70, 145S-148S. [CrossRef]

5. Freedman, D.S.; Khan, L.K.; Dietz, W.H.; Srinivasan, S.R.; Berenson, G.S. Relationship of childhood obesity to coronary heart disease risk factors in adulthood: The Bogalusa Heart Study. Pediatrics 2001, 108, 712-718. [CrossRef]

6. Freedman, D.S.; Kettel Khan, L.; Serdula, M.K.; Srinivasan, S.R.; Berenson, G.S. BMI rebound, childhood height and obesity among adults: The Bogalusa Heart Study. Int. J. Obes. Relat. Metab. Disord. 2001, 25, 543-549. [CrossRef]

7. Cunningham, S.A.; Kramer, M.R.; Narayan, K.M. Incidence of childhood obesity in the United States. N. Engl. J. Med. 2014, 370, 1660-1661. [CrossRef]

8. Tounian, P. Programming towards childhood obesity. Ann. Nutr. Metab. 2011, 58, 30-41. [CrossRef]

9. Hanson, M.A.; Gluckman, P.D. Early developmental conditioning of later health and disease: Physiology or pathophysiology? Physiol. Rev. 2014, 94, 1027-1076.

10. Waterland, R.A. Epigenetic mechanisms affecting regulation of energy balance: Many questions, few answers. Annu. Rev. Nutr. 2014, 34, 337-355. [CrossRef]

11. Burdge, G.C.; Lillycrop, K.A. Nutrition, epigenetics, and developmental plasticity: Implications for understanding human disease. Annu. Rev. Nutr. 2010, 30, 315-339. [CrossRef] [PubMed]

12. Langley-Evans, S.C. Nutrition in early life and the programming of adult disease: A review. J. Hum. Nutr Diet. 2015, 28, 1-14. [CrossRef] [PubMed]

13. Hussain, N. Epigenetic influences that modulate infant growth, development, and disease. Antioxid. Redox Signal. 2012, 17, 224-236. [CrossRef] [PubMed]

14. Feinberg, A.P. Epigenetics at the epicenter of modern medicine. JAMA 2008, 299, 1345-1350. [CrossRef] [PubMed]

15. Demetriou, C.A.; van Veldhoven, K.; Relton, C.; Stringhini, S.; Kyriacou, K.; Vineis, P. Biological embedding of early-life exposures and disease risk in humans: A role for DNA methylation. Eur. J. Clin. Investig. 2015, 45, 303-332. [CrossRef] [PubMed]

16. Kuehnen, P.; Mischke, M.; Wiegand, S.; Sers, C.; Horsthemke, B.; Lau, S.; Keil, T.; Lee, Y.A.; Grueters, A.; Krude, H. An Alu element-associated hypermethylation variant of the POMC gene is associated with childhood obesity. PLoS Genet. 2012, 8, e1002543. [CrossRef] [PubMed]

17. Relton, C.L.; Groom, A.; St Pourcain, B.; Sayers, A.E.; Swan, D.C.; Embleton, N.D.; Pearce, M.S.; Ring, S.M.; Northstone, K.; Tobias, J.H.; et al. DNA methylation patterns in cord blood DNA and body size in childhood. PLoS ONE 2012, 7, e31821. [CrossRef] 
18. Azzi, S.; Sas, T.C.; Koudou, Y.; Le Bouc, Y.; Souberbielle, J.C.; Dargent-Molina, P.; Netchine, I.; Charles, M.A. Degree of methylation of ZAC1 (PLAGL1) is associated with prenatal and post-natal growth in healthy infants of the EDEN mother child cohort. Epigenetics 2014, 9, 338-345.

19. Perng, W.; Mora-Plazas, M.; Marin, C.; Rozek, L.S.; Baylin, A.; Villamor, E. A prospective study of LINE-1DNA methylation and development of adiposity in school-age children. PLoS ONE 2013, 8, e62587. [CrossRef]

20. Sharp, G.C.; Lawlor, D.A.; Richmond, R.C.; Fraser, A.; Simpkin, A.; Suderman, M.; Shihab, H.A.; Lyttleton, O.; McArdle, W.; Ring, S.M.; et al. Maternal pre-pregnancy BMI and gestational weight gain, offspring DNA methylation and later offspring adiposity: Findings from the Avon Longitudinal Study of Parents and Children. Int. J. Epidemiol. 2015, 44, 1288-1304. [CrossRef]

21. Wang, S.; Song, J.; Yang, Y.; Zhang, Y.; Wang, H.; Ma, J. HIF3A DNA Methylation Is Associated with Childhood Obesity and ALT. PLoS ONE 2015, 10, e0145944. [CrossRef] [PubMed]

22. Huang, R.C.; Garratt, E.S.; Pan, H.; Wu, Y.; Davis, E.A.; Barton, S.J.; Burdge, G.C.; Godfrey, K.M.; Holbrook, J.D.; Lillycrop, K.A. Genome-wide methylation analysis identifies differentially methylated CpG loci associated with severe obesity in childhood. Epigenetics 2015, 10, 995-1005. [CrossRef] [PubMed]

23. van Dijk, S.J.; Peters, T.J.; Buckley, M.; Zhou, J.; Jones, P.A.; Gibson, R.A.; Makrides, M.; Muhlhausler, B.S.; Molloy, P.L. DNA methylation in blood from neonatal screening cards and the association with BMI and insulin sensitivity in early childhood. Int. J. Obes. 2018, 42, 28-35. [CrossRef] [PubMed]

24. Gagne-Ouellet, V.; Houde, A.A.; Guay, S.P.; Perron, P.; Gaudet, D.; Guerin, R.; Jean-Patrice, B.; Hivert, M.F.; Brisson, D.; Bouchard, L. Placental lipoprotein lipase DNA methylation alterations are associated with gestational diabetes and body composition at 5 years of age. Epigenetics 2017, 12, 616-625. [CrossRef] [PubMed]

25. Groom, A.; Potter, C.; Swan, D.C.; Fatemifar, G.; Evans, D.M.; Ring, S.M.; Turcot, V.; Pearce, M.S.; Embleton, N.D.; Smith, G.D.; et al. Postnatal growth and DNA methylation are associated with differential gene expression of the TACSTD2 gene and childhood fat mass. Diabetes 2012, 61, 391-400. [CrossRef]

26. Rzehak, P.; Covic, M.; Saffery, R.; Reischl, E.; Wahl, S.; Grote, V.; Weber, M.; Xhonneux, A.; Langhendries, J.P.; Ferre, N.; et al. DNA-Methylation and Body Composition in Preschool Children: Epigenome-Wide-Analysis in the European Childhood Obesity Project (CHOP)-Study. Sci. Rep. 2017, 7, 14349. [CrossRef]

27. Godfrey, K.M.; Sheppard, A.; Gluckman, P.D.; Lillycrop, K.A.; Burdge, G.C.; McLean, C.; Rodford, J.; Slater-Jefferies, J.L.; Garratt, E.; Crozier, S.R.; et al. Epigenetic gene promoter methylation at birth is associated with child's later adiposity. Diabetes 2011, 60, 1528-1534. [CrossRef]

28. Kresovich, J.K.; Zheng, Y.; Cardenas, A.; Joyce, B.T.; Rifas-Shiman, S.L.; Oken, E.; Gillman, M.W.; Hivert, M.F.; Baccarelli, A.A.; Hou, L. Cord blood DNA methylation and adiposity measures in early and mid-childhood. Clin. Epigenet. 2017, 9, 86. [CrossRef]

29. Lillycrop, K.; Murray, R.; Cheong, C.; Teh, A.L.; Clarke-Harris, R.; Barton, S.; Costello, P.; Garratt, E.; Cook, E.; Titcombe, P.; et al. ANRIL Promoter DNA Methylation: A Perinatal Marker for Later Adiposity. EBioMedicine 2017, 19, 60-72. [CrossRef]

30. Borengasser, S.J.; Baker, P.R.; Kerns, M.E.; Miller, L.V.; Palacios, A.P.; Kemp, J.F.; Westcott, J.E.; Morrison, S.D.; Hernandez, T.L.; Garces, A.; et al. Preconception Micronutrient Supplementation Reduced Circulating Branched Chain Amino Acids at 12 Weeks Gestation in an Open Trial of Guatemalan Women Who Are Overweight or Obese. Nutrients 2018, 10, 1282. [CrossRef]

31. Peng, S.; Deyssenroth, M.A.; Di Narzo, A.F.; Cheng, H.; Zhang, Z.; Lambertini, L.; Rusualepp, A.; Kovacic, J.C.; Bjorkegren, J.L.M.; Marsit, C.J.; et al. Genetic regulation of the placental transcriptome underlies birth weight and risk of childhood obesity. PLoS Genet. 2018, 14, e1007799. [CrossRef] [PubMed]

32. Boeke, C.E.; Oken, E.; Kleinman, K.P.; Rifas-Shiman, S.L.; Taveras, E.M.; Gillman, M.W. Correlations among adiposity measures in school-aged children. BMC Pediatr. 2013, 13, 99. [CrossRef] [PubMed]

33. Freedman, D.S.; Wang, J.; Ogden, C.L.; Thornton, J.C.; Mei, Z.; Pierson, R.N.; Dietz, W.H.; Horlick, M. The prediction of body fatness by BMI and skinfold thicknesses among children and adolescents. Ann. Hum. Biol. 2007, 34, 183-194. [CrossRef] [PubMed]

34. Loos, R.J.; Katzmarzyk, P.T.; Rao, D.C.; Rice, T.; Leon, A.S.; Skinner, J.S.; Wilmore, J.H.; Rankinen, T.; Bouchard, C. Genome-wide linkage scan for the metabolic syndrome in the HERITAGE Family Study. J. Clin. Endocrinol. Metab. 2003, 88, 5935-5943. [CrossRef]

35. Zhang, X.; Yang, W.; Wang, J.; Meng, Y.; Guan, Y.; Yang, J. FAM3 gene family: A promising therapeutical target for NAFLD and type 2 diabetes. Metabolism 2018, 81, 71-82. [CrossRef] 
36. Chen, Z.; Ding, L.; Yang, W.; Wang, J.; Chen, L.; Chang, Y.; Geng, B.; Cui, Q.; Guan, Y.; Yang, J. Hepatic Activation of the FAM3C-HSF1-CaM Pathway Attenuates Hyperglycemia of Obese Diabetic Mice. Diabetes 2017, 66, 1185-1197. [CrossRef]

37. Maatta, J.A.; Bendre, A.; Laanti, M.; Buki, K.G.; Rantakari, P.; Tervola, P.; Saarimaki, J.; Poutanen, M.; Harkonen, P.; Vaananen, K. Fam3c modulates osteogenic cell differentiation and affects bone volume and cortical bone mineral density. Bonekey Rep. 2016, 5, 787. [CrossRef]

38. Barry, F.P.; Murphy, J.M. Mesenchymal stem cells: Clinical applications and biological characterization. Int. J. Biochem. Cell Biol. 2004, 36, 568-584. [CrossRef]

39. Jiang, Y.; Jahagirdar, B.N.; Reinhardt, R.L.; Schwartz, R.E.; Keene, C.D.; Ortiz-Gonzalez, X.R.; Reyes, M.; Lenvik, T.; Lund, T.; Blackstad, M.; et al. Pluripotency of mesenchymal stem cells derived from adult marrow. Nature 2002, 418, 41-49. [CrossRef]

40. Hoffman, T.L.; Javier, A.L.; Campeau, S.A.; Knight, R.D.; Schilling, T.F. Tfap2 transcription factors in zebrafish neural crest development and ectodermal evolution. J. Exp. Zool. B Mol. Dev. Evol. 2007, 308, 679-691. [CrossRef]

41. de Croze, N.; Maczkowiak, F.; Monsoro-Burq, A.H. Reiterative AP2a activity controls sequential steps in the neural crest gene regulatory network. Proc. Natl. Acad. Sci. USA 2011, 108, 155-160. [CrossRef] [PubMed]

42. Mifflin, S.W.; Strack, A. Obesity and the central nervous system. J. Physiol. 2007, 583 Pt 2, 423. [CrossRef]

43. Wenke, A.K.; Rothhammer, T.; Moser, M.; Bosserhoff, A.K. Regulation of integrin alpha10 expression in chondrocytes by the transcription factors AP-2epsilon and Ets-1. Biochem. Biophys. Res. Commun. 2006, 345, 495-501. [CrossRef]

44. Wenke, A.K.; Bosserhoff, A.K. Roles of AP-2 transcription factors in the regulation of cartilage and skeletal development. FEBS J. 2010, 277, 894-902. [CrossRef]

45. Wenke, A.K.; Grassel, S.; Moser, M.; Bosserhoff, A.K. The cartilage-specific transcription factor Sox9 regulates AP-2epsilon expression in chondrocytes. FEBS J. 2009, 276, 2494-2504. [CrossRef] [PubMed]

46. Niebler, S.; Schubert, T.; Hunziker, E.B.; Bosserhoff, A.K. Activating enhancer binding protein 2 epsilon (AP-2epsilon)-deficient mice exhibit increased matrix metalloproteinase 13 expression and progressive osteoarthritis development. Arthritis. Res. Ther. 2015, 17, 119. [CrossRef] [PubMed]

47. Welter, D.; MacArthur, J.; Morales, J.; Burdett, T.; Hall, P.; Junkins, H.; Klemm, A.; Flicek, P.; Manolio, T.; Hindorff, L.; et al. The NHGRI GWAS Catalog, a curated resource of SNP-trait associations. Nucleic Acids Res. 2014, 42, D1001-D1006. [CrossRef] [PubMed]

48. Speliotes, E.K.; Willer, C.J.; Berndt, S.I.; Monda, K.L.; Thorleifsson, G.; Jackson, A.U.; Lango Allen, H.; Lindgren, C.M.; Luan, J.; Magi, R.; et al. Association analyses of 249,796 individuals reveal 18 new loci associated with body mass index. Nat. Genet. 2010, 42, 937-948. [CrossRef] [PubMed]

49. Thorleifsson, G.; Walters, G.B.; Gudbjartsson, D.F.; Steinthorsdottir, V.; Sulem, P.; Helgadottir, A.; Styrkarsdottir, U.; Gretarsdottir, S.; Thorlacius, S.; Jonsdottir, I.; et al. Genome-wide association yields new sequence variants at seven loci that associate with measures of obesity. Nat. Genet. 2009, 41, 18-24. [CrossRef]

50. Willer, C.J.; Speliotes, E.K.; Loos, R.J.; Li, S.; Lindgren, C.M.; Heid, I.M.; Berndt, S.I.; Elliott, A.L.; Jackson, A.U.; Lamina, C.; et al. Six new loci associated with body mass index highlight a neuronal influence on body weight regulation. Nat. Genet. 2009, 41, 25-34.

51. Lindgren, C.M.; Heid, I.M.; Randall, J.C.; Lamina, C.; Steinthorsdottir, V.; Qi, L.; Speliotes, E.K.; Thorleifsson, G.; Willer, C.J.; Herrera, B.M.; et al. Genome-wide association scan meta-analysis identifies three Loci influencing adiposity and fat distribution. PLoS Genet 2009, 5, e1000508. [CrossRef]

52. Elboudwarej, E.; Cole, M.; Briggs, F.B.; Fouts, A.; Fain, P.R.; Quach, H.; Quach, D.; Sinclair, E.; Criswell, L.A.; Lane, J.A.; et al. Hypomethylation within gene promoter regions and type 1 diabetes in discordant monozygotic twins. J. Autoimmun. 2016, 68, 23-29. [CrossRef] [PubMed]

53. Boras, M.; Volmering, S.; Bokemeyer, A.; Rossaint, J.; Block, H.; Bardel, B.; Van Marck, V.; Heitplatz, B.; Kliche, S.; Reinhold, A.; et al. Skap2 is required for beta2 integrin-mediated neutrophil recruitment and functions. J. Exp. Med. 2017, 214, 851-874. [CrossRef] [PubMed]

54. Huang, H.; Song, T.J.; Li, X.; Hu, L.; He, Q.; Liu, M.; Lane, M.D.; Tang, Q.Q. BMP signaling pathway is required for commitment of $\mathrm{C} 3 \mathrm{H} 10 \mathrm{~T} 1 / 2$ pluripotent stem cells to the adipocyte lineage. Proc. Natl. Acad. Sci. USA 2009, 106, 12670-12675. [CrossRef] [PubMed] 
55. Hu, J.; Lu, J.; Lian, G.; Ferland, R.J.; Dettenhofer, M.; Sheen, V.L. Formin 1 and filamin B physically interact to coordinate chondrocyte proliferation and differentiation in the growth plate. Hum. Mol. Genet. 2014, 23, 4663-4673. [CrossRef]

56. Li, C.X.; Gao, Y.; Gao, W.J.; Yu, C.Q.; Lyu, J.; Lyu, R.R.; Duan, J.L.; Sun, Y.; Guo, X.H.; Wang, S.F.; et al. Association between obesity and DNA methylation among the 7-16 year-old twins. Zhonghua Liu Xing Bing Xue Za Zhi 2018, 39, 443-448.

57. Cardenas, A.; Gagne-Ouellet, V.; Allard, C.; Brisson, D.; Perron, P.; Bouchard, L.; Hivert, M.F. Placental DNA Methylation Adaptation to Maternal Glycemic Response in Pregnancy. Diabetes 2018, 67, 1673-1683. [CrossRef]

58. Zadora, J.; Singh, M.; Herse, F.; Przybyl, L.; Haase, N.; Golic, M.; Yung, H.W.; Huppertz, B.; Cartwright, J.E.; Whitley, G.; et al. Disturbed Placental Imprinting in Preeclampsia Leads to Altered Expression of DLX5, a Human-Specific Early Trophoblast Marker. Circulation 2017, 136, 1824-1839. [CrossRef]

59. Mitsuya, K.; Parker, A.N.; Liu, L.; Ruan, J.; Vissers, M.C.M.; Myatt, L. Alterations in the placental methylome with maternal obesity and evidence for metabolic regulation. PLoS ONE 2017, 12, e0186115. [CrossRef]

60. Guillemette, L.; Allard, C.; Lacroix, M.; Patenaude, J.; Battista, M.C.; Doyon, M.; Moreau, J.; Menard, J.; Bouchard, L.; Ardilouze, J.-L.; et al. Genetics of Glucose regulation in Gestation and Growth (Gen3G): A prospective prebirth cohort of mother-child pairs in Sherbrooke, Canada. BMJ Open 2016, 6, e010031. [CrossRef]

61. Fraser, W.D.; Shapiro, G.D.; Audibert, F.; Dubois, L.; Pasquier, J.C.; Julien, P.; Berard, A.; Muckle, G.; Trasler, J.; Tremblay, R.E.; et al. 3D Cohort Study: The Integrated Research Network in Perinatology of Quebec and Eastern Ontario. Paediatr. Perinat. Epidemiol. 2016, 30, 623-632. [CrossRef] [PubMed]

62. Wells, J.C.; Fewtrell, M.S. Measuring body composition. Arch. Dis. Child. 2006, 91, 612-617. [CrossRef] [PubMed]

63. Pidsley, R.; Zotenko, E.; Peters, T.J.; Lawrence, M.G.; Risbridger, G.P.; Molloy, P.; Van Djik, S.; Muhlhausler, B.; Stirzaker, C.; Clark, S.J. Critical evaluation of the Illumina MethylationEPIC BeadChip microarray for whole-genome DNA methylation profiling. Genome Biol. 2016, 17, 208. [CrossRef] [PubMed]

64. Moran, S.; Arribas, C.; Esteller, M. Validation of a DNA methylation microarray for 850,000 CpG sites of the human genome enriched in enhancer sequences. Epigenomics 2016, 8, 389-399. [CrossRef]

65. Aryee, M.J.; Jaffe, A.E.; Corrada-Bravo, H.; Ladd-Acosta, C.; Feinberg, A.P.; Hansen, K.D.; Irizarry, R.A. Minfi: A flexible and comprehensive Bioconductor package for the analysis of Infinium DNA methylation microarrays. Bioinformatics 2014, 30, 1363-1369. [CrossRef]

66. Fortin, J.P.; Labbe, A.; Lemire, M.; Zanke, B.W.; Hudson, T.J.; Fertig, E.J.; Greenwood, C.M.; Hansen, K.D. Functional normalization of 450k methylation array data improves replication in large cancer studies. Genome Biol. 2014, 15, 503. [CrossRef]

67. Xu, Z.; Langie, S.A.; De Boever, P.; Taylor, J.A.; Niu, L. RELIC: A novel dye-bias correction method for Illumina Methylation BeadChip. BMC Genom. 2017, 18, 4. [CrossRef]

68. Logue, M.W.; Smith, A.K.; Wolf, E.J.; Maniates, H.; Stone, A.; Schichman, S.A.; McGlinchey, R.E.; Milberg, W.; Miller, M.W. The correlation of methylation levels measured using Illumina 450K and EPIC BeadChips in blood samples. Epigenomics 2017, 9, 1363-1371. [CrossRef]

69. Johnson, W.E.; Li, C.; Rabinovic, A. Adjusting batch effects in microarray expression data using empirical Bayes methods. Biostatistics 2007, 8, 118-127. [CrossRef]

70. Andrews, S.V.; Ladd-Acosta, C.; Feinberg, A.P.; Hansen, K.D.; Fallin, M.D. "Gap hunting” to characterize clustered probe signals in Illumina methylation array data. Epigenetics Chromatin 2016, 9, 56. [CrossRef]

71. Du, P.; Zhang, X.; Huang, C.C.; Jafari, N.; Kibbe, W.A.; Hou, L.; Lin, S.M. Comparison of Beta-value and M-value methods for quantifying methylation levels by microarray analysis. BMC Bioinform. 2010, 11, 587. [CrossRef] [PubMed]

72. Meller, M.; Vadachkoria, S.; Luthy, D.A.; Williams, M.A. Evaluation of housekeeping genes in placental comparative expression studies. Placenta 2005, 26, 601-607. [CrossRef] [PubMed]

73. Murthi, P.; Fitzpatrick, E.; Borg, A.J.; Donath, S.; Brennecke, S.P.; Kalionis, B. GAPDH, 18S rRNA and YWHAZ are suitable endogenous reference genes for relative gene expression studies in placental tissues from human idiopathic fetal growth restriction. Placenta 2008, 29, 798-801. [CrossRef] [PubMed]

74. Drewlo, S.; Levytska, K.; Kingdom, J. Revisiting the housekeeping genes of human placental development and insufficiency syndromes. Placenta 2012, 33, 952-954. [CrossRef] 
75. Fox, J.M.; Levine, S.E.; Clark, D.S.; Blanch, H.W. Initial- and processive-cut products reveal cellobiohydrolase rate limitations and the role of companion enzymes. Biochemistry 2012, 51, 442-452. [CrossRef]

76. Rahmani, E.; Zaitlen, N.; Baran, Y.; Eng, C.; Hu, D.; Galanter, J.; Oh, S.; Burchard, E.G.; Eskin, E.; Zou, J. Sparse PCA corrects for cell type heterogeneity in epigenome-wide association studies. Nat. Methods 2016, 13, 443-445. [CrossRef]

77. Pedersen, B.S.; Schwartz, D.A.; Yang, I.V.; Kechris, K.J. Comb-p: Software for combining, analyzing, grouping and correcting spatially correlated P-values. Bioinformatics 2012, 28, 2986-2988. [CrossRef]

(C) 2020 by the authors. Licensee MDPI, Basel, Switzerland. This article is an open access article distributed under the terms and conditions of the Creative Commons Attribution (CC BY) license (http://creativecommons.org/licenses/by/4.0/). 